\title{
Bodybuilders as Vigilantes and Vigilantes as Perpetrators of Election Violence: True?
}

\author{
Ishmael Norman $\mathbb{1}$ \\ Institute for Security, Disaster and Emergency Studies, Langma, Ghana \\ Email: ishmael_norman@yahoo.com, ishmael.norman@isdesghana.org
}

How to cite this paper: Norman, I. (2019). Bodybuilders as Vigilantes and Vigilantes as Perpetrators of Election Violence: True? Advances in Applied Sociology, 9, 208-226. https://doi.org/10.4236/aasoci.2019.96017

Received: May 21, 2019

Accepted: June 18, 2019

Published: June 21, 2019

Copyright $\odot 2019$ by author(s) and Scientific Research Publishing Inc. This work is licensed under the Creative Commons Attribution International License (CC BY 4.0).

http://creativecommons.org/licenses/by/4.0/

\begin{abstract}
In Sub-Saharan Africa, bodybuilders have been demonized as Vigilantes who are not violence averse, and who cause election violence. The situation is more complex and does not provide a straight forward cause and effect approach. This is an investigation into the relationship between bodybuilding and political party vigilantism and the role these actors play in election violence. The author used mixed methodology of analytical literature review and ethnographical investigative tool. Observer-Participant studied 16 bodybuilders in an Accra City Gym to determine if bodybuilding predisposes one to Political Party Vigilantism and consequently to election violence. Prompted by the generally known fact that some recreational and professional athletes' use Anabolic-Androgenic Steroids, AAS for performance enhancement and image improvement, the association between AAS and increased aggression and violence was reviewed (Hoskin \& Ellis, 2015). The investigation appears to suggest that the national media may be justified for painting some bodybuilders as testosterone driven, thrill seekers who morph into vigilante groups with the propensity for violence (Beaver et al., 2008; Piacentico, Kotzalidis, del Casale et al., 2015). This finding was not sustained by other researchers (Bahsin, Storer, Berman et al., 1996; Yates et al., 1999). In the national situation, the youth appear to use bodybuilding as part of their healthseeking needs, although there are aspects of bodybuilding that may not contribute to overall good health, such as the injection of steroids for muscle mass. Those recruited into Political Party Vigilante Groups join through peer recommendation, Political Party affiliation, personal choice and direct employment by "strongmen and financiers" in the Political Parties. A more objective approach to reporting on, and understanding of bodybuilding and its association with vigilantism or election violence should be adopted. Political Party vigilantism appears to be an effect of systemic economic malaise and under-development, which ought to be addressed by central government through progressive investment in education and employment opportunities.
\end{abstract}




\section{Keywords}

Body-Building, Anabolic-Androgenic Steroids, Vigilantism, Election Violence

\section{Introduction}

Writing about the sport of bodybuilding in the United States of America, Cortese (2014) cited two pieces of literature that seem to underscore the perceived violence associated with bodybuilding even in Ghana. Granted, all the referenced papers were about the perception of the sport, the use and abuse of AAS in the Western Industrialized nations and not about bodybuilders as members of vigilante groups in a middle income nation such as Ghana. He cited that, "we are entering a golden age of drug development. The use of... substances in athletics will grow proportionately.... It will be... critical... both medically and philosophically" (Wu \& von Eckardstein, 2003; Cortese, 2014). He added that "you cannot hold a comprehensive discussion about bodybuilding without talking about the use of anabolic steroids and other performance-enhancing drugs (Phillips, 1997, 2004; Cortese, 2014). Although the topic for this paper is about the demonization of bodybuilders specifically in Ghana and in Sub-Saharan Africa generally, it was necessary to discuss the sub-culture of bodybuilding in relation to some of the allegations and negative conduct of some bodybuilders about which the media has reported and the public has complained.

The sport of bodybuilding is not inherently violent. To understand the reasons for the condemnation, it is important to review what researchers have found about the sport. It is because; and as reported by various researchers, "males who had used anabolic-androgenic steroids at least once in their life reported greater involvement in violent behavior compared with males who reported never using anabolic-androgenic steroids" (Beaver et al., 2008: p. 2186). Anabolic Androgenic Steroids, AAS use has led to "evolutionary neuro-androgenic" theory, ENA (Hoskin \& Ellis, 2015). ENA theorizes that "brain exposure to both prenatal and post-pubertal androgens (particularly testosterone) promotes all forms of competitiveness, including those that victimize others". Other researchers have linked exposure to fetal testosterone and other androgens prenatally may increase the probability of offending later in life (Hoskin \& Ellis, 2015; Turanovic et al., 2017). Not all researchers agree with the issue of a single dose exposure to AAS leading to profound neuro-adaptive changes. Others have refuted the single dose exposure theory with "premorbid abnormal personalities or those with a history of psychiatric disorders who are attracted to AAS use" (Piacentico, Kotzalidis, del Casale et al., 2015).

Another group of researchers contributed that, a single exposure to AAS may not determine ethnic differences to the escalation or de-escalation of conflict and that "the causes of ethnic differences in criminal behavior are more compli- 
cated than simple exposure to androgens" (Winegard \& Winegard, 2018: p. 122). These apposite views are not opposite to each other, but rather add on or build on the scientific efforts to understand the effects of nonmedical "roids" (slang for steroids) use or consumption. It has been reported that some of the negative side effects of AAS include complications such as "hypertension, atherosclerosis, myocardial hypertrophy and infarction, abnormal blood clotting, hepatotoxity and psychiatric" as well as "behavioral symptoms like aggressiveness and irritability" (Stannard \& Bucknell, 1993; Hartgens \& Kuipers, 2004; Talih, Fattal, \& Malone, 2007; Piacentico et al. 2015). Yet, there are other researchers that have reported beneficial effects from AAS, including "the treatment of HIV-related muscle wasting, muscle dystrophies, severe burn injuries, bone marrow failure, hereditary angioedema and growth retardation in children" (Gelfand, Sherins, Alling, \& Frank, 1976; Ammus, 1989; Piacentico et al., 2015). How do all the research and clinical findings relate to Political Party Vigilantism and the subsequent eruption of election violence, perpetrated; often times; by men with purposely sculptured muscularity?

Although there are many influential published works on various aspects of political vigilantism in Sub-Saharan Africa, for example in Tanzania (Fleisher, 2000; Abrahams, 1998; Bukurura, 1994), and in Kenya (Anderson, 1986; Fleisher, 1998) to mention but a few, there has not been direct links to bodybuilding as, probably, the "boot camp" for developing "vigilante personality" that can be energized to violent ends by soaring political party rhetoric and the promise of financial reward. It is the combination of strong looking, muscular men, who may be booted by steroids with all of its psychiatric effects and affects, to either protect ballot boxes, or stall the opposition party's advances that, raises the specter of fear and doom in the opponent and the resulting violence or clash. There are Vigilante Groups with deep affiliations with, or sponsorship of national political parties within Sub-Saharan Africa such as those of Ghana (Gyampo et al., 2017), Kenya (Kioko, 2010), South Africa (Theodore Petrus, 2015; West Cape Government, Occasional Paper, 2013), and in Nigeria (Spencer \& Moraro, 2017). Despite the widespread nature of the practice and the negative impact it appears to exert on the democratization process of Sub-Saharan Africa, "there is as yet no scholarly consensus on what exactly vigilantism is-especially as regards the nature of its relationship with the state" (Sederberg and Rosenbaum 1976; 1974: 542). Sederberg and Rosenbaum, defined vigilantism to mean "to take the law in one's hands, a sort of do-it-yourself justice when resorting to all other established means fails". Johnston (1996: p. 222) defined vigilantism from criminological viewpoint to mean "to be alert". Vigilantes are first responders "to danger or to detect danger" (Johnston, 1996). Other researchers such as Kowalewski (1982) and Little \& Sheffield (1983) defined vigilantism to mean "establishment violence", perpetrated in furtherance of "conservative" ends, and "designed to create, maintain, or recreate an established socio-political order" (Fleisher, 2000: p. 209; Norman, 2019). The author would now link the previous narrative to the issue of election violence. 
When it comes to communication about election violence, there appears to be overwhelming confusion even among scholars, let alone the media about who or what should be held culpable. Every actor in the creation of election violence passes the buck to another player without self-introspection or equivocation. Staniland has offered that "electoral violence has been poorly conceptualized". That, "the term is used to refer to wildly different phenomena, from crackdowns by security forces to violence perpetrated by political parties' armed wings to insurgent targeting of politicians during campaigns. This has created a conceptual and empirical muddle that undermines explanations for the causes of "electoral violence" (Staniland, 2014: p. 100). This description applies to the situation in Ghana and in Sub-Saharan Africa in general. Staniland cautions that in addition to studying the consequences of election related violence, "scholars need to dramatically broaden how electoral violence is understood: it does not just involve rioting thugs controlled by cunning politicians, but can also include coups, insurgencies, brutal state crackdowns, and local clashes fueled by community rivalries" (Straus \& Taylor, 2008; Bekoe, 2008; Staniland, 2014).

Despite such warning and instruction, the national discourse on election violence does not appear to delve into the primary causes of election violence but often scapegoats Political Party Vigilante Groups as the culprits (CODEO, 2017; National Commission for Civic Education, 2019; AG, Ghana, 2019). The shortcoming cannot be put only on the media alone, but even on departments and agencies and on the national law makers. The nation appears to view or define Vigilante Groups as bodybuilders, macho men with big muscles and big bodies, who enforce law and order for the respective parties that have such wings.

Added to the scholarly and policy confusion surrounding the perpetrators of election violence is the real fact that Ghana appears to have too many media houses and radio stations all competing for the same story, all providing nuance angles to the same story and trying to be the first in news (TV3 promo: Best in News, First in News, 2019). Such intra-media house competition is generally considered healthy for democracy, freedom of the press and speech. However, it also poses severe threat to the peace and tranquility of the nation, perhaps, much in the same way that all organizational excesses could be disruptive to the normal functioning of society. Ghana has over 392 radio stations, [or 1:76,530 inhabitants] 128 television stations, [or 1:234,375 inhabitants] and with a total national population of approximately 30 million

(https://www.nca.org.gh/media-and-news/news/authorised-fm-radio-stations-as -at-second-quarter-of-2017/;

http://worldpopulationreview.com/countries/ghana-population/). In addition to these tele-communication infrastructure, there are more than a dozen newspapers, bloggers and other internet based news and entertainment outlets. Due to their sheer numbers, when the collective media cluster around an issue, that issue becomes an instant national obsession, gaining wild currency.

Many of the media houses do well presenting programs that enhance national 
development and peace building at the lower echelon of society in terms of sanitation, hygiene and security, public information, entertainment and politics. Their reach, however, is not as effective in dealing with matters that concern the upper middle classes, the rich and powerful, or the information needs of those in the upper echelons of society that are self-made, or captains of industries and those within the intellectual classes, especially those in academia and in research. When it comes to the universities and centers of learning, the moments one reads or hears about developments in those places are when there are scandals, violence or abuse of office. The Ghanaian media does not have time to investigate discoveries being made by research institutions, discoveries and publications being done by other researchers and are not even interested to talk to Principal Investigators on truly original research done in the nation. There are often no progressive or novel news about manufacturing, true new business development, no news on incubation laboratories whose works may bescalable and capable of improving job creation, or news on how access to capital can be improved. Business news is often short in duration compared to the ample time given to valueless entertainment news. Almost all television stations in Ghana present mediocre international news clips during the evening news that are not worth the spittle of the presenters. The business news is often about fraud, Ponzi schemes, cheating and dishonest managers, and doom. Such news items could have the consequential effect of disrupting national peace and development if fake or malicious (Stephanie Sullivan, personal communication, US Ambassador to Ghana, 4/2019).

In the last 12 months, almost every operating television and radio station in the nation has carried a news story, discussion panel, call-ins and text-ins on the issue of bodybuilders as vigilantes or as militia. Some even label those members of the Vigilante groups that are into bodybuilding as "brainless chauvinists". Such accusations and labels are nowhere more voluble as in election related violence and agitations (CODEO, 2019; Staniland, 2014). But election violence is not the exclusive purview of bodybuilders who are vigilantes but the government and the parliamentarians as well as the general public that contribute to the often partisan national discourse in diverse ways. "Elections can fuel violence where the contestants do not follow the rules or accept the election outcome as the legitimate expression of the will of the citizenry. They are not the sole cause of pre- or postelection violence" (AU Panel of the Wise, 2010: p. 11; https://www.ipinst.org/).

Ghana witnessed politically related violence perpetrated by an alleged Political Vigilante Group members during a recent By-Election at Ayawaso West Wuogon, Accra. At that event, alleged affiliated New Patriotic Party, NPP's Vigilante Group, who masquerading as members of the National Security personnel, attacked the opposition National Democratic Party members in the house of the NDC candidate for that By-election. Before uniform police officers and television cameras, some of the alleged NPP Vigilante Group members, who were carrying small arms, discharged over 20 rounds of ammunition from AK 47 and 
other hand guns, apparently at the NDC supporters. During this moment, one of the alleged NPP Vigilante Group members, slapped a sitting NDC member of the Ghanaian Parliament, all captured by television cameras, voters and by-standers with cell phone cameras. The gun shots, the assault of the NDC Parliamentarian, and the confusion that ensued both at the polling grounds at Ayawaso and in the nation, led to calls from many sources and voices to disband the known Vigilante Groups with political party affiliations. The Vigilante Groups in Ghana include: Invisible Force, Bamba Boys, Bolga Bulldogs, Kandahar Boys, Delta Force, the Hawks, Azorka Boys, Eastern Mambas, Gbewa Youth, to name but a few. They first emerged as rag-tag body-builders with no unifying ideology, purpose or interests, with brawny, street-smarts alertness and, decidedly, masculine bodies. To many admirers of such physique, the muscularity of their bodies represents youthfulness, even healthiness, but it may also represent visual intimidation, violence, and even fear (Taylor \& Mensah, 2017; Cortese, 2014).

Soon thereafter this incident, on February 6, 2019, the government set up the Emile Short Commission of inquiry to investigate the developments leading up to the Ayawaso West Wuogon By-election confrontation. Its terms of reference were: "To make a full, faithful and impartial enquiry into the circumstances of, and establish the facts leading to, the events and associated violence during the Ayawaso West Wuogon by-election. To identify any person responsible for or who has been involved in the events, the associated violence and injuries. To inquire into any matter which it considers incidental or reasonably related to the causes of the events and the associated violence and injuries, and to submit within one month its report to the President, giving reasons for its findings and recommendations, including appropriate sanctions, if any" (Awuni, 2019) (https://www.myjoyonline.com/politics/2019/February-11th/) accessed, 5/16/10. It started its inquiry on $11^{\text {th }}$ February, 2019.

While the Short Commission was busy building up data on the violence, on or about the $7^{\text {th }}$ of March, a 22-minute documentary by the Multimedia Network, Kokomlemle, Accra, was aired under the title, "Militia in the heart of the nation". It alleged that a militia (De Eye Group) was in fact training at the old seat of government, Christianborg Castle, Osu, in Accra. The area is designated as a security zone and that the alleged training of the De-Eye Group was with the complicity of the government, since that group was allegedly part of the NPP. A petition dated March 13, 2019 was filled by the Minister of Information with the National Media Commission asserting that the documentary was "misleading and constituted a dishonest and deliberate misrepresentation of facts calculated to cause" among others, "alarm and panic" (https://youtube.be/RdZSOkMxET8; https://www.myjoyonline.com).

The dramatic promo that aired prior to the main act, used footage from the Ayawaso West Wuogon confrontation, under the authorship of a well-known reporter, Manasseh Azure Awuni. The documentary for a while, threw the national media discourse into serious disarray and damnation of vigilante groups 
of all types and purposes. Issues of national development, youth disenfranchisement and female empowerment among others, were pushed to the backburner in the ensuing cacophony of political, religious and pseudo-psychological analyses of bodybuilding, election violence, offending personality types and other derisive ascriptions.

\section{Method}

\subsection{Ethnographical Approach to Field Work}

Ethnographical field observation was carried out in an Accra City gym with 16 subjects over a six month period between April, 2018 and September, 2018. Prior to the in-depth study, the researcher had been a member of the same gym for over three years, and had previously been a member of exercise clubs since 1998 in various suburbs of Accra City. Embed approach was in line with ethnographic methodology, where the Observer-Participant employs "systematic description of events being observed, the behaviors, and artifacts in the social setting", and with great care of registering or recording what is being observed, and with patience (Marshall and Rossman, 1989; DeWalt \& DeWalt, 2002). Gym visits were on weekends where most of the patrons exercised at this center. Some of the big gym facilities in Accra City have dedicated spaces for aerobics exercise, equipment for regular workout, and heavy weights section for the bodybuilders, although any club member could be in any of the sections without being barred. The gym in the study had similar layout. A daily routine began with stretching, warm-up exercises including the use of treadmills of various kinds, and continued through light weight training. Some patrons concentrated on only aerobic exercise, which was in a different part of this gym. It was observed that a few women were involved in bodybuilding in the gym in the study, although most women visited the gym for aerobic workouts. Those found in the "heavy weights" section of the gym, were in the company of male companions, who were themselves bodybuilders. It may not have been culturally appropriate to talk to the woman, by engaging the woman on issues of training, dieting and food supplements before their companions. Due to differential training styles of men and women, which could have skewed the data due to inherent sex bias, the 16 subjects were all men. Notice that participant observational research requires a certain degree of deception (Bernard, 1994). Knowing that there was "no harm" in collecting information on the culture of bodybuilders in a public space, the subjects were approached with sincerity and a desire to know more about bodybuilding, without making a full disclosure of the purpose behind the visits (DeMunck \& Sobo, 1998). It was observed the gym had training coaches who took new members and weekend visitors through the paces to avoid injury. Gym members were approached randomly in the first instant and then established a rapport. This was reasonably easy to do because the Observer-Participant was known to the bodybuilders, having been a member of the club for some time before the commencement of the study. This was continued until the desired 
number of subjects was obtained. A kind of camaraderie developed over time between the researcher and some of the study subjects, through sharing of pleasantries, fresh fruits and bottles of mineral water, although this did not create bias due to the emotional detachment employed. Notice that the topic did not arouse deep emotions or attachments, making it easier to remain uninvolved emotionally with the subjects. Thereafter, contacts were made in the Gym only and during visits. Among the 16 subjects who were all bodybuilders in the study, Gym attendance was ritualistically regular, with occasional absence due to illness or family emergencies. All 16 participants visited the gym with punctuality and in earnest, except three of the subjects who were stricken by malaria and another who was away from the Gym for 2 months, due to death in his family. The Observer-Participant also missed a total of two weeks of gym attendance due to work assignments and trips outside Accra City.

\subsection{Literature Search Approach}

Altogether, 56 pertinent publications were reviewed for this paper spread among the major themes of bodybuilding, anabolic-androgenic steroids use, and vigilantism and election violence. There was a loose inclusion criteria, using the snowball effect. The investigation started from the key paper, then searched the reference list to locate more relevant papers. Inclusion of a paper in this list was whether it addressed any of the three themes. Search engines included PubMed, Goggle Scholar, ScienceDirect, Scopus, Medical and Psychiatric Journals, as well as Journals on Criminology and Violence, Political Science and the Humanities.

To identify appropriate literature, different permutations were used in the search, which included "links between vigilantism and bodybuilding, Ghana" which yielded [9 results]. "Demonization of vigilantism in Ghana's Media”, [8 results]; but "Causes of Vigilantism" yielded [741,000 results] consisting of blogs, news files, reports, scholarly papers and anecdotal images on bodybuilding or the youth. "Effects of political vigilantism in Ghana", [319,000 result] and the "History of political vigilantism in Ghana" [427,000 result]. These were broadened to include: "bodybuilding and vigilantism" [58,000 result], "the use of Anabolic Androgenic Steroids and bodybuilding", "the use of food supplements and bodybuilding", and "the effects of dietary supplements among bodybuilders in Ghana". Most of the results produced by the search on the World Wide Web did not directly relate or address the topic or sub-themes of the topic, although a handful of the papers alluded to aspects of vigilantism and political violence on one hand. On the other hand, another small group of papers treated the effects of dietary supplements on bodybuilders in Ghana focusing on those in the universities (Taylor \& Mensah, 2017). Although inconclusive, a single report appeared to have "fingered" bodybuilding groups as causative agents of political vigilantism (https://www.atinkaonline.com/tv/body-building-groups). Most papers, whether grey or scholarly generally talked about the issue of vigilantism being the cause of election violence in abstraction with a few ones doing a 
painstaking job of diagnosing the phenomena of bodybuilders, vigilantes and offending types.

\subsection{Literature Linking Bodybuilding to Anabolic-Androgenic Steroids Use and Offending}

Current research and emerging theories of criminality vis-à-vis recreational use and abuse of anabolic-androgenic steroids, was reviewed given the commonly known fact that many members of the Vigilante Groups in Ghana, are, in fact, body-builders (National Commission for Civic Education, 2019; Taylor \& Mensah, 2017). Some use commercially available or home-made supplements for muscle growth and rejuvenation and, which may contain testosterone and other androgenic properties. As suggested in some of the papers reviewed, "androgen exposure is associated with criminality and that, with a few exceptions, androgen exposure generally varies ethnically in ways that match criminal behavior" (Hoskin \& Ellis, 2015; Winegard \& Winegard, 2018: p. 122; Beaver, Vaughn, DeLisi, \& Wright, 2008: p. 2186). Information culled from the pertinent sources consisting of 56 papers were organized into their various units and analyzed, based on the professional understanding of the author of bodybuilding, vigilantism, and election violence. The result from this work is not meant to be generalized, but to help understand how the public through the media treats phenomena that appear to threaten the ontological security of the state and the individuals.

\section{Result and Discussion}

\subsection{Field Report from Participant Observation}

The Observer-Participant ethnographically studied 16 subjects who were amateur bodybuilders over a (6) six month period in an Accra City gym between April, 2018 and September, 2018. This formed part of a larger study on vigilantism and election violence out of which three other papers have been produced for publication. During the six month-long observational work at the gym, no demographic data was collected from the subjects. The Observer-participant had known all the subjects previously as members of the same gym. Some of their ages and occupations were already known to the Observer-participant through social activities such as celebration of birthdays, and other social engagements. A reasonable estimate would put about $60 \%$ of the subjects between ages 20 and 35 . Another 30\% were between ages 36 and 45 with the rest being slightly older oryounger. There was no recordation of any kind in the Gym Clubs, since such a device would have caused great consternation and disaffection. All recordation was done after the visit in the car, office or home of the Observer-participant.

During site visits, informal conversations about general dieting and exercise, were had intermittently with other trainers and bodybuilders in addition to the type of suitable exercises and required repetitions per exercise type. In some of these conversations, food supplements specifically calibrated for bodybuilders were discussed with those who appeared to be bodybuilders, and sometimes at 
the counter in the reception's vitrine, where some well-known brands were offered for sale. It was found that whenever the Observer-Participant "complained" about not gaining muscle mass or raised other physique issues in pretense, appropriate food supplements were recommended by training coaches and other bodybuilders with whom rapport had developed and a semblance of friendship was budding.

A good number of the bodybuilders were engaged in various economic activities. Some were petty traders and operators of car washing bays, mobile phone sellers, butchers, and drinking spots operators.

Although not study participants, it has been observed that more and more professional class men and women were also being attracted to the sport and, thus gradually, changing the trend since gyms and exercise clubs became available in affluent neighborhoods, such as Accra Fitness Center, Osu; DansomanKeepfit Club; Maximum Gym, Dansoman; Pippas, Cantonments and Osu; Aviation Social Center, Airport, Pulse Fitness Ghana, Gold Gym, Sel Fitness, Decathlon, Bling Body Gym, University of Ghana Gym Center, and many others beginning from the 1990s. Today, many hotels and even some guest houses and companies have exercise gyms, and quite a number of affluent households have private gyms.

The researcher did not observe any subject ingesting any other substance, or taking a pill, or injections of any substance, except water or juice in clear plastic water bottles during the course of the study. None of the 16 subjects drunk coffee or any other stimulant as beverage, except during special club get together where alcoholic beverages, beer and wine were served together with food. If the athletes were using AAS or other supplements, it was done in the most private or secretive way, which a cross-sectional study may have helped to uncover. However, from conversations with several of the subjects, it was confirmed that about $24 \%$ to $50 \%$ of the bodybuilders injected steroids for muscle mass and definition. The informants also confirmed occasionally injecting themselves with steroids for the same goals as the others. That, almost all of them used supplements, which were either locally purchased or sent to them by friends and relatives from UK and USA and from other markets. It was revealed that some of them consumed about four to six high protein meals a day particularly when preparing for national competitions, and then taper off from the use of steroids a week or so before competition as well as cut down on the amount of protein intake.

\subsection{The Public Perception of Bodybuilding}

Bodybuilding as a sport is both admired and derided by members of the general public, although there appears to be the general admission that the sport helps the youth to become more disciplined, particularly among university students studied at the Kwame Nkrumah University of Science and Technology (Taylor and Mensah, 2017). Although there is no epidemiological study of the ills or benefits of bodybuilding as a sport on a nation-wide basis in Ghana, it appears 
everyone has an opinion about the sport and those who practice it. Bodybuilding or body sculpturing is both an art and a health-seeking behavior, although there are those who see only the negative aspect of the sport (Taylor \& Mensah, 2017). The negativity associated with the sports partially lie with political parties, the governments, departments and agencies, the Ministry of Youth and Sport for the level of attention these pay to the sport, and largely to the bodybuilders. It appears some of these public institutions have not done the basic work of conducting epidemiological studies to ascertain what really pertains in the world of bodybuilding and its possible links to vigilantism, or election violence. Instead, some; if not all of the public institutions issue emotional, unsupported statements and reports (with slogans as "say no to political thugs") blaming the youth and bodybuilders as the casual agents of political vigilantism (National Commission for Civic Education, 2019). Ghana's post-modern cultural and cosmopolitan life, more or less is imported from Britain and the USA. In UK alone, it is "currently estimated there are around 60,000 steroid users, although some believe the figure to be, unofficially, closer to a million", and in the United States of America, at least, two million people are engaged in AAS use (https://www.youtube.com/watch?v=vQr6yFbthY8; Cortese, 2014). The few published works on bodybuilding in Ghana affirmed the use of natural or commercial food supplements and ingestion of large amounts of protein foods by university based bodybuilders. This raised the suspicion that, perhaps, some of the athletes in that study, may be using anabolic-androgenic steroids, AAS "as part of a healthy lifestyle... gain self-confidence, have a change in physique, and to look good" (Taylor \& Mensah, 2017).

Although the use of muscle mass enhancement in bodybuilding is not an often discussed topic by the national media, there are often rumored mention of its use by a certain group of bodybuilders and some of the vigilantes. In about $75 \%$ of the time spent at the gym on this study, it was found that food supplements were sold over the counter to any member who had the purchasing power. Such supplements are promoted as healthy, which are meant to ensure lean bodies, increase muscle mass and definition, without mention of the presence of AAS. Other opportunistic traders join exercise centers to push their food supplements to their members. In variably, bodybuilding and vigilantism are closely associated phenomena where the use of supplements or anabolic-androgenic steroids, AAS may be secretly consumed. In the case of Ghana, many of the men engaged in Vigilante Group activities, are, in fact, body-builders, who may be using AAS or natural supplements. Some of them are, perhaps, habitual users of anabolic-androgenic steroids as well as home-made food supplements" (Angoorani \& Halabchi, 2015; Cortese, 2014; Winegard \& Winegard, 2018, Norman, 2019). The foregoing lays the foundation why vigilantes are strongly associated with bodybuilding and why there is so much media and public vilification against the sport. Going by violent or disruptive actions undertaken by various groups of vigilantes in the past, and in relation to election violence, it is quite tempting to 
make the hasty conclusion that bodybuilders strongly equate vigilantism and therefore are violent (National Commission for Civic Education, 2019).

\subsection{Employment Opportunities and Social Networks}

The statistics on youth unemployment and opportunities available to the majority of the people of many nations in Africa, Ghana not exempted, is widely accessible in many government and Internet sources. It is also famously known how difficult it is for well-established businesses in Sub-Saharan African economies to raise capital, irrespective of having great business plans, collateral or good market shares in the particular industries in which they are engaged. It is even more difficult for experienced young men and women to raise any form of capital except those they could attract from family, parents or themselves. Except for scholastic value, it makes no sense to keep repeating such data from one paper to the other (Di Tella \& Schargrodsky, 2003; Easterly \& Ross, 1997; Easterly, 2001, 2007). Particularly because economic development is not the focus of this paper, this author is not going to engage in egoistical recitation of the statistical deprivation and inequities in the national or Sub-Saharan Africa's economies. By and large, the economic paradigm which is being run in most African nations today, are stacked against the upward mobility of the youth, women, the vulnerable, the politically unconnected, the religiously unconnected and the academically un-credentialed (Association of African Universities, 2017).

Although about half of the subjects studied in this paper lived in their own rented units, with another quarter owning their own homes, the others were temporarily "perching" or living with friends or family due to the lack of money to defray the cost of a two year rent advance payment for an apartment. About $70 \%$ of the subjects had jobs or were engaged in productive activities, whiles the rest were unemployed and depended on the generosity of their peer, friends, and visitors to the gym. The number that had jobs or who were engaged in productive activities, also rode motorcycles and, or drove their own cars to and fro the gym. Whether in deed the vehicles belonged to them or someone else cannot be ascertained. Of the group of bodybuilders that had no jobs and who had, perhaps, given up looking, they hanged around the gym, offered to help new comers or visitors to train, or solicited for business as private trainers from the seemingly well to do members of the Gym Clubs.

Almost all the 16 subjects talked often about becoming professional bodybuilders in the UK or the USA. Therefore, becoming an amateur bodybuilder with hopes of graduating to professional class is part of the dreams of young but economically disadvantaged men in Ghana. Bodybuilders in the UK or USA may not face the same or even similar economic challenges such as the lack of access to good but basic housing, inability to secure three square meals a day, lack of jobs or employment no matter how menial, let alone spend about $\$ 300$ to $\$ 400$ a year on food supplements. However, some bodybuilders in the Western Industrial economies give economic justifications why they go into bodybuilding: to 
increase their social profile, body mass, muscle mass, to compete for laurels and for sponsorships, and to gain respect (Taylor \& Mensah, 2017).

In order for some of the national bodybuilders raise capital, they avail themselves as executive body-guards, night-club bouncers, props at fashion shows, and ushers at big public events. In fact, for some of the young men engaged in bodybuilding, the motivation for the sport was to improve their chances for such engagements. Bodybuilding therefore is a type of self-help project that enables the athlete to brand himself as a product, a profit center, without engaging in vice such as male prostitution or criminal activity. The discipline learned in the gym in sculpturing their bodies is often transferred to running the type of businesses that their meagre capital can help to launch: spare parts dealerships, car washing bays, drinking spots, barbering, tailoring, and such other trades and economic activities. Those that are politically connected are able to be enrolled in the police service or the national army, sometimes, without regard to their academic abilities or achievements.

The exercise Gym is a place of bonding and socialization as well as networking. From field observations, it has been noted that many of the athletes in amateur bodybuilding have suffered or suffer from social deprivation, economic underclassness and want. At the gym they develop enabling connections and network that may help them to direct their skills into productive activities as they build up their egos and self-image.

\subsection{Political Party Recruitment}

It was observed among the 16 subjects in this study that they appeared to have highly developed sense of politics and political competition in Ghana. They were committed to the particular political party they were aligned with and viewed life in "we versus them" equation. Despite the fact that they appeared as ardent supporters of their political parties, they were not particularly crazy about or committed to sacrificing their lives for the life of even their most favorite politician. Collectively, bodybuilders were optimistic group of people. At least, optimism for the future was detected among those studied. They talked often about what their plans were for the future, with slogans like, "the young shall grow", "no weapon can defeat us" and "it shall be well". These are all messages of hope, and not of destruction and mayhem as some commentators have reported.

Those recruited into the reported Political Party Vigilante Groups, join through peer recommendation or pressure, Political Party affiliation, personal choice and direct employment by "strongmen and financiers" in the Political Parties as personal body-guards and party security men. They were financially sponsored by the political parties. On this concern, the report of the National Commission For Civic Education stating that, "there are kingpins in the National Democratic Congress, NDC and New Patriotic Party, NPP who allegedly resourced and sponsored these violent groups and therefore these groups perceive their "services" as a means of income, was supported by what had been observed 
(National Commission for Civic Education, 2019: p. 13). Bodybuilders that were really buffed, chiseled out with big biceps and triceps often got noticed very quickly if they were also naturally gifted with height and imposing structural frame. Some of those studied reported of having been co-opted into the security details of prominent national political operatives and who often travelled with such operatives to various social and official engagements.

It has also been noted that "the insatiable desire of leadership of the two major political parties to win power at all cost, resorted to using the youth groups to intimidate their opponents to achieve this desire" (National Commission for Civic Education, 2019: p. 13). This means the bigger the bodybuilder, the greater the fear or intimidation factor he exuded on the opponent. Some of the subjects in this study provided anecdotal narratives on their personal experiences to validate this observation by the NCCE and others. These groups also existed or participated in "different behaviors to maximize inclusive fitness" (Winegard \& Winegard, 2018; Norman, 2019).

\subsection{Bodybuilding and Links to Aggressive, Offending Behavior vis-à-vis Election Violence}

In the national media and reports of other public and non-governmental institutions, it is established, though without a national empirical study that, bodybuilding strongly associate with offending behavior. That may explain why bodybuilders who are political party vigilantes tend to apply the tools of intimidation and violence for the mitigation of conflict. There is research from other places that tend to support the local assertion regarding the use of intimidation techniques by the vigilantes. In order to apply the findings of researchers in other places to the national experience, it has to be assumed that bodybuilders in Ghana, without empirical data, consume anabolic androgenic steroids as this research has found. As earlier reported, during the 6-month long ethnographical investigation, none of the 16 subjects studied was observed ever taking any supplement or drug, or pill apart from water or what appeared to be unadulterated water. It has also been reported that, perhaps, the dosing of supplements by bodybuilders in the Gym visited during the observational study do in fact, take AAS but privately in their abodes before they got to the Gym to workout. Having made these declarations, it is fair to accept the preposition that other researchers have found that "elevations in testosterone stemming from anabolic-androgenic steroid use may have purported links to aggressive and violent behaviors" (Beaver et al., 2008: p. 2185; Skarberg \& Engstrom, 2007; Thiblim \& Parlklo, 2002; Pope, Kouri, \& Hudson, 2000; Conacher \& Workman, 1989). The several studies carried out among bodybuilders in Ghana did not build up to this conclusion because their foci were on renal health management and not on behavioral outcomes of bodybuilders (Taylor \& Mensah, 2017). In a study among Iranian recreational bodybuilders, the authors found in a self-report of AAS abuse was registered in $16.6 \%$ of those in the study, and that "among different psy- 
cho-socio-demographic factors, only family income and sport experience were inversely associated with AAS abuse" (Angoorani \& Halabchi, 2015). Perhaps, due to difficult financial situation in which many of the bodybuilders in Ghana live, which is no different from their counterparts in their age and economic cohorts, this fact may mitigate against the abuse of AAS due to cost considerations.

\section{Conclusion}

The issue of election violence coupled with youth restlessness and propensity to violence whether it is fueled by Anabolic-Androgenic Steroids, alcohol, drugs use or the soaring sermons of a religious cleric, whether in a gang, vigilante group or militia is a very scary thought for both the establishment and members of the youth. This is because all admit that the leadership of these nations, Ghana not exempted, and the adult members who were to guide the public purse, have not done their nations well in Sub-Saharan Africa. Economic hardships largely created by the leaders of these nations and the governments have forced thousands of young people to undertake perilous journeys across the desert and then over the ocean to Europe for greener pastures. Those who stay behind and who join vigilante groups, and who engage in violence of any type, though not justified, appear to have very little option by way of job opportunities. They also are victims of the perceived and real neglect of the affairs of the nation by the governments and by the adult leaderships. Those who go into bodybuilding appear desperate, and pursue any avenue that would bring them what appears to be a faux sense of fulfillment. This too is a natural outcome of unmet economic employment needs and the resulting restlessness. The finding that about $24 \%$ to $50 \%$ of the bodybuilders injected steroids for muscle mass and definition, and that almost all of the bodybuilders including those 16 study participants use supplements, should be of concern to public health authorities and policy makers in Ghana. It should be borne in mind that neither the use nor abuse of AAS, or membership in a vigilante group is the reason why there is election violence in Ghana and in Sub-Saharan African generally. There is election violence in Ghana because the adult members of the political parties appear to be on suicide mission where the "winner takes all" mentality rules, even if the rest of the nation would blow up in flames. When it comes to election violence, it appears those that need to be put in check are not the bodybuilders but the adult politicians and their hangers-on. The government and other entities should therefore refrain from demonizing bodybuilders as trouble makers, although they may have their own challenges as athletes.

\section{Study Limitations}

The use of this study is cautioned. Wishing to make this study a truly national one, and at the same time confronted with the paucity of refereed national publications, only 56 pertinent publications were reviewed for this paper most of 
which were by other researchers about their national situations. The general national literature gap, contributed to limiting the paper's breadth in a significant way in terms of its general application. The study population is too small to be used in generalizations. Ethnographical studies tend to suffer from bias and subjectivity, perhaps, unlike the other forms of empirical studies. This study could have benefited from a cross-sectional or qualitative research to ascertain the habits, views and perception of bodybuilders and their use of AAS. Data could also have been collected from the Political Parties for recruiting bodybuilders into their vigilante groups, as alleged by the NCCE's report of 2019 on election violence. No demographical data was gained from this study with respect to the use or abuse of anabolic androgen steroids, AAS and their historical involvement in violence, crime or other aggressive behaviors. Despite these remarks, this study offers important contribution to the literature within Sub-Saharan Africa on the possible connection between bodybuilding, AAS use, vigilantes and their relationship to Political Parties and election violence. Perhaps, future research work may explore these factors to add to the literature on Vigilante Groups and the sport of body-building as well as the use of AAS. This author wishes to disassociate from the impression that all bodybuilders use, or bodybuilding leads to the use of AAS. This paper also shows that although there appears to be established connection between AAS and violence, and psychiatric challenges, the research did not concern a national validation investigation of these phenomena.

\section{Conflicts of Interest}

The author declares no conflicts of interest regarding the publication of this paper.

\section{References}

Abrahams, R. (1998). Vigilant Citizens: Vigilantism and the State. Cambridge: Polity Press.

Ammus, S. S. (1989). The Role of Androgens in the Treatment of Hematologic Disorders. Advances in Internal Medicine, 34, 191-208.

Angoorani, H., \& Halabchi, F. (2015). The Misuse of Anabolic-Androgenic Steroids among Iranian Recreational Male Body-Builders and Their Related Psycho-SocioDemographic Factors. Iranian Journal of Public Health, 44, 1662-1669.

Association of African Universities (2017). https://events.aau.org/gencon14/wp-content/uploads/sites/2/2016/11/CONCEPT-PAP ER_AAU-GENERAL-CONFERENCE-AND-GOLDEN-JUBILEE-2017.pdf

AU Panel of the Wise (2010). Election-Related Disputes and Political Violence: Strengthening the Role of the African Union in Preventing, Managing and Resolving Conflict. The African Union Series, New York: International Peace Institute. https://www.ipinst.org

Awuni, M. A. (2019). Militia in the Heart of the Nation. https://www.myjoyonline.com/Militiadocumentary_Manassehrespondstogovernment NMCpetition_GeneralNews2019-04-02.mhtml

Beaver, K. M., Vaughn, M. G., DeLisi, M., \& Wright, J. P. (2008). Anabolic-Androgenic 
Steroid Use and Involvement in Violent Behavior in a Nationally Representative Sample of Young Adult Males in the United States. American Journal of Public Health, 98, 2185-2187. https://doi.org/10.2105/AJPH.2008.137018

Bernard, H. R. (1994). Research Methods in Anthropology: Qualitative and Quantitative Approaches (2nd ed.). Walnut Creek, CA: Alta Mira Press.

Bhasin, S., Storer, T. W., Berman, N. et al. (1996). The Effects of Supraphysiologic Doses of Testosterone on Muscle Size and Strength in Normal Men. The New England Journal of Medicine, 335, 1-7. https://doi.org/10.1056/NEJM199607043350101

Bukurura, S. H. (1994). The Maintenance of Order in Rural Tanzania: The Case of Sungusungu. Journal of Legal Pluralism and Unofficial Law, 34, 1-29. https://doi.org/10.1080/07329113.1994.10756453

CODEO (2017). CODEO Post-Election Environment Observation Report.

CODEO (2019). CODEO-Communique-6 April, 2017.

Conacher, G. N., \& Workman, D. G. (1989). Violent Crime Possibly Associated with Anabolic Steroid Use. American Journal of Psychiatry, 146, 679.

Cortese, A. (2014). Muscle as Fashion: Messages from the Bodybuilding Subculture. American Medical Association Journal of Ethics, 16, 565-569. https://doi.org/10.1001/virtualmentor.2014.16.07.msoc1-1407

De Munck, V. C., \& Sobo, E. J. (1998). Using Methods in the Field: A Practical Introduction and Casebook. Walnut Creek, CA: AltaMira Press.

DeWalt, K. M., \& DeWalt, B. R. (2002). Participant Observation: A Guide for Fieldworkers. Walnut Creek, CA: AltaMira Press.

Di Tella, R., \& Schargrodsky, E. (2003). The Role of Wages and Auditing during a Crackdown on Corruption in the City of Buenos Aires. Journal of LaW \& Economics 46, 269-292. http://www.lacea.org/meeting2000/RafaelDiTella2.PDF https://doi.org/10.1086/345578

Easterly, W. (2001). The Middle Class Consensus and Economic Development. Journal of Economic Growth, 6, 317-335. https://doi.org/10.1023/A:1012786330095

Easterly, W. (2007). Inequality Does Cause Underdevelopment: Insights from a New Instrument. Journal of Development Economics, 84, 755-776.

https://doi.org/10.1016/j.jdeveco.2006.11.002

Easterly, W., \& Ross, L. (1997). Africa's Growth Tragedy: Policies and Ethnic Divisions. The Quarterly Journal of Economics, 112, 1203-1250.

https://doi.org/10.1162/003355300555466

https://williameasterly.files.wordpress.com/2010/08/17_easterly_levine_africasgrowthtr agedy_prp.pdf

Fleisher, L. M. (2000). "Sungusungu”: State-Sponsored Village Vigilante Groups among the Kuria of Tanzania. Journal of the International African Institute, 70, 209-228. https://doi.org/10.3366/afr.2000.70.2.209

Gelfand, J. A., Sherins, R. J., Alling, D. W., \& Frank, M. M. (1976). Treatment of Hereditary Angioedema with Danazol: Reversal of Clinical and Biochemical Abnormalities. The New England Journal of Medicine, 295, 1444-1448. https://doi.org/10.1056/NEJM197612232952602

Gyampo, E. R., Graham, E., \& Asare, E. B. (2017). Political Vigilantism and Democratic Governance in Ghana's Fourth Republic. African Review, 44, 112-135.

Hartgens, F., \& Kuipers, H. (2004). Effects of Androgen-Anabolic Steroids in Athletes. Sports Medicine, 34, 513-554. https://doi.org/10.2165/00007256-200434080-00003

Hoskin, A. W. \& Ellis, L. (2015). The Evolutionary Neuroandrogenic Theory of Criminal 
Behavior Expanded. Aggression and Violent Behavior, 24, 61-74. https://doi.org/10.1016/j.avb.2015.05.002

Johnston, L. (1996). What Is Vigilantism? British Journal of Criminology, 36, 220-236. https://doi.org/10.1093/oxfordjournals.bjc.a014083

Kowalewski, D. (1982). Establishment Vigilantism and Political Dissent: A Soviet Case Study. Armed Forces \& Society, 9, 83-97. https://doi.org/10.1177/0095327X8200900106

Little, C. B., \& Sheffield, C. P. (1983). Frontiers and Criminal Justice: English Private Prosecution Societies and American Vigilantism in the Eighteenth and Nineteenth Centuries. American Sociological Review, 48, 796-808. https://doi.org/10.2307/2095326

National Commission for Civic Education (2019). NCCE Report.

Norman, I. D. (2019). A Prospective Evaluation of the Vigilantism and Related Offences Bill, 2019. Accra: Institute for Security, Disaster and Emergency Studies. http://www.isdesghana.org

Phillips, S. M. (2004). Protein Requirements and Supplementation in Strength Sports. Nutrition, 20, 689-695. https://doi.org/10.1016/j.nut.2004.04.009

Phillips, W. (1997). Sports Supplement Review. Denver, CO: Mile High Publishing.

Piacentico, D., Kotzalidis, G. D., del Casale, A., Aromatario, M. R., Pomara, C., Girardi, P., \& Sani, G. (2015). Anabolic-Androgenic Steroids Use and Psychopathology in Athletes: A Systematic Review. Current Neuropharmacology, 13, 101-121. https://doi.org/10.2174/1570159X13666141210222725

Pope, H. G., Kouri, E. M., \& Hudson, J. I. (2000). Effects of Supra-Physiologic Doses of Testosterone on Mood and Aggression in Normal Men: A Randomized Controlled Trial. Archives of General Psychiatry, 57, 133-140. https://doi.org/10.1001/archpsyc.57.2.133

Sederberg, P. C., \& Rosenbaum, H. J. (1974). Vigilantism: An Analysis of Establishment Violence. Comparative Politics, 6, 541-556.

Sederberg, P. C., \& Rosenbaum, H. J. (1976). Vigilantism: An Analysis of Establishment Violence. In H. Jon Rosenbaum, \& P. C. Sederberg (Eds.), Vigilante Politics (pp. 3-29). Philadelphia, PA: University of Pennsylvania Press. https://doi.org/10.9783/9781512806335

Skarberg, K., \& Engstrom, I. (2007). Troubled Social Background of Male Anabolic-Androgenic Steroid Abusers in Treatment. Substance Abuse Treatment, Prevention, and Policy, 2, 20. https://doi.org/10.1186/1747-597X-2-20

Spencer, L., \& Moraro, P. (2017). Vigilantism Is Flourishing in Nigeria with Official Support.

https://theconversation.com/vigilantism-is-flouring-in-nigeria-with-official-support-86 $\underline{867}$

Staniland, P. (2014). Violence and Democracy. Comparative Politics, 47, 99-118. https://doi.org/10.5129/001041514813623128

Stannard, J. P., \& Bucknell, A. L. (1993). Rupture of the Triceps Tendon Associated with Steroid Injection. The American Journal of Sports Medicine, 21, 482-485. https://doi.org/10.1177/036354659302100327

Stephanie Sullivan, Personal Communication, US Ambassador to Ghana, 4/2019.

Straus, S., \& Taylor, C. (2012). Democratization and Electoral Violence in Sub-Saharan Africa, 1990-2008. In D. Bekoe (Ed.), Voting in Fear: Electoral Violence in Sub-Saharan Africa (pp. 15-38). Washington DC: United States Institute of Peace.

Talih, F., Fattal, O., \& Malone, D. Jr. (2007). Anabolic Steroid Abuse Psychiatric and Physical Costs. Cleveland Clinic Journal of Medicine, 74, 341-352. 
https://doi.org/10.3949/ccjm.74.5.341

Taylor, J., \& Mensah, W. (2017). Effects of Nutritional and Dietary Supplements on Renal Function among University Bodybuilders in Ghana. International Annals of Medicine, 1. https://doi.org/10.24087/IAM.2017.1.10.278

Thiblim, I., \& Parlklo, T. (2002). Anabolic Androgenic Steroids and Violence. Acta Psychiatrica Scandinavica, 412, 125-128. https://doi.org/10.1034/j.1600-0447.106.s412.27.x

Turanovic, J. J., Pratt, T. C., \& Piquero, A. R. (2017). Exposure to Fetal Testosterone, Aggression, and Violent Behavior: A Meta-Analysis of the 2D:4D Digit Ratio. Aggression and Violent Behavior, 33, 51-61. https://doi.org/10.1016/j.avb.2017.01.008

Winegard, B. M., \& Winegard, Bo. M. (2018). The Emerging Science of Evolutionary Criminology. Journal of Criminal Justice, 59, 133-126. https://doi.org/10.1016/j.jcrimjus.2018.05.006

Wu, F. C., \& von Eckardstein, A. (2003). Androgens and Coronary Artery Disease. Endocrine Reviews, 24, 183-217. https://doi.org/10.1210/er.2001-0025

Yates, W. R., Perry, P. J., Macindoe, J. et al. (1999). Psychosexual Effects of Three Doses of Testosterone Cycling in Normal Men: A Controlled Personality Study. Biological Psychiatry, 45, 254-260. https://doi.org/10.1016/S0006-3223(98)00028-6 